\title{
OPEN
}

Published online: 20 November 2019

\section{Author Correction: Genomic Prediction of 16 Complex Disease Risks Including Heart Attack, Diabetes, Breast and Prostate Cancer}

\author{
Louis Lello, Timothy G. Raben, Soke Yuen Yong, Laurent C. A. M. Tellier \& Stephen D. H. Hsu \\ Correction to: Scientific Reports https://doi.org/10.1038/s41598-019-51258-x, published online 25 October 2019 \\ In this Article, the authors neglected to include some potential conflicts of interest. The Competing Interests \\ section should read: \\ "Laurent Tellier is an employee, shareholder, and serves on the board of directors of the company Genomic \\ Prediction, Inc. Stephen Hsu is a shareholder and serves on the board of directors of Genomic Prediction, Inc. \\ Louis Lello had no affiliation with Genomic Prediction, Inc. during the research, writing, and submission of this \\ paper, but joined the company just before the paper was accepted. The other authors have no commercial interests \\ relevant to the research."
}

\begin{abstract}
(c) (i) Open Access This article is licensed under a Creative Commons Attribution 4.0 International C. License, which permits use, sharing, adaptation, distribution and reproduction in any medium or format, as long as you give appropriate credit to the original author(s) and the source, provide a link to the Creative Commons license, and indicate if changes were made. The images or other third party material in this article are included in the article's Creative Commons license, unless indicated otherwise in a credit line to the material. If material is not included in the article's Creative Commons license and your intended use is not permitted by statutory regulation or exceeds the permitted use, you will need to obtain permission directly from the copyright holder. To view a copy of this license, visit http://creativecommons.org/licenses/by/4.0/.
\end{abstract}

(C) The Author(s) 2019 